\title{
Child Migration in the US and Spain: Towards a Global Border Regime?
}

\begin{abstract}
In The New Politics of Immigration, Professor Catherine Dauvergne proposes that as migration policies converge at the global level the traditional difference between settler societies and former European colonies is becoming irrelevant. To test this argument, this paper addresses the impact of externalization, militarization, detention and deportation on unaccompanied migrant children along the southern Spanish and US borders. I conclude that the combined used of these strategies is designed to keep all unwanted migrants away from the physical border of the state regardless of their background and prevents children from accessing specific protections. Current border policy in these two countries shows the primacy of national security concerns over human rights and supports Dauvergne's argument that distinctions between former colonies and settler societies are disappearing. The evidence considered here points towards an increasingly restrictive and punitive global border regime, but one with regional variations.
\end{abstract}

\section{ACKNOWLEDGEMENTS}

I would like to thank the members of the Migration Research Collective, particularly Jenny Francis, Yolande Pottie-Sherman, Stephanie Silverman, and Lyubov Zhyznomirska for their comments on a previous version of this chapter. The thoughtful and generous feedback of the two anonymous reviewers also made this a better paper. This research was supported by the Fonds de recherche du Québec - Société et culture (Grant no. 2019-NP-253366). All mistakes are my own. 


\section{INTRODUCTION}

The border is at the centre of contemporary efforts to stop the movement of spontaneous (and unwanted) human mobility. Reluctant states of reception have created a hostile border architecture to stop the arrival of the "less deserving" - particularly spontaneous migrants from poorer nations with racialized backgrounds. The four pillars of this hostile architecture are construction of new (and reinforcement of existing) militarized border walls and fences worldwide, which includes unprecedented investment in border technology (Topak and Vives, 2018; Vallet 2013, 2017); externalization of border control responsibilities to countries of origin and transit of international migration (Casas-Cortés et al., 2014; Loyd and Mountz, 2018); increasing importance of deportation (Gibney, 2008; Hiemstra, 2019); and the unprecedented reliance on migrant detention (González Sánchez, 2016; Hiemstra, 2019). Countries across the Global North have justified these measures on the basis of national security and the fight against global terrorism. The emergence of a common way of conceiving the role of the border for the purposes of migration control calls into question traditional distinctions between settler states (i.e., the USA) and former colonial states (i.e., Great Britain) in migration scholarship, leading observers to point to the development of a global border regime (Dauvergne, 2016; Jones, 2016; Maillet et al., 2018).

This new border has a distinct impact on unaccompanied and separated migrant children (henceforth "unaccompanied migrant children" or "migrant children"). The securitization and criminalization of spontaneous international migration has led to an increasing tension between international human rights instruments such as the Convention on the Rights of the Child (CRC) and national legislations (which tend to reflect international commitments) on the one hand; and 
national migration law and its actual implementation, on the other. Punitive migration policies at the border are increasingly at odds with states' international, regional, and domestic legal obligations and commitments to shelter and protect these minors (Bhabha 2014a, 2014b).

In this paper I focus on the migration of unaccompanied minors to test the limits of the global border argument and evaluate the impact initiatives to realize it have on them. The discussion compares two places that are emblematic of a novel way of implementing restrictive border policies: Spain and the US. This comparison allows me to test Dauvergne's argument that the new politics of immigration have moved beyond traditional distinctions between former European colonial states (e.g. France, Germany, or Spain) and settler states (e.g. Canada, the USA, and Australia). The thematic focus on migrant children, meanwhile, highlights the impact of this tension between national security concerns and the protection of migrants at risk, and engages with Dauvergne's assertion that we are moving towards a new global approach to international migration defined by its "nastiness" towards (racialized) migrants.

The discussion starts with a brief introduction to the concept of unaccompanied migrant children and an overview of their participation in spontaneous migrations along the southern US and the Spanish-EU borders. In the next two sections I focus on particularly "nasty" defensive border policies that target spontaneous migration in these two locales and their impact on child migration: externalization, militarization, detention, and deportation. This discussion uses secondary sources such as scientific papers, policy documents, government and NGO reports and media coverage of relevant events. In the conclusions, I reflect on the overall impact of these measures on the protection of migrant children's rights, and on how attention to regional variations of this Global border regime adds nuance to the convergence argument without invalidating it. 


\section{UNACCOMPANIED AND SEPARATED MIGRANT CHILDREN IN SPAIN AND THE US}

Unaccompanied and separated migrant children are minors under the age of 18 who are outside their country of origin and have been separated from both parents and any other relatives and adults who, by law or custom, are responsible for their care (Committee on the Rights of the Child, General Comment no. 6, 2005, articles 7 and 8). This is a heterogeneous category. Some children are alone, while others may travel with other children or adults; some are asylum seekers or refugees, while others aspire to work and financially support their families by working in destination countries; they may travel on their own accord or be victims of human trafficking; some migrate without their parents, while others are separated along the way; they can be infants, toddlers, young children, or adolescents nearing adulthood.

Despite these differences, all unaccompanied migrant children are considered at risk of violence and exploitation and are accorded specific protections under a broad range of international and regional instruments. Globally, the CRC (1990) provides the most comprehensive and targeted protection for foreign-born children (Arts. 1 and 22). The CRC is the most widely ratified human rights treaty in history. Both the USA and Spain are signatories of the CRC, although the USA is yet to ratify it. The two countries are also signatories of other treaties that specifically address the rights of migrant children, such as the 1951 Geneva Convention Relative to the Status of Refugees and the 1967 Protocol and the 1949 Geneva Convention Relative to the Protection of Civilian Persons in Time of War. Furthermore, through their commitment to the $\mathrm{CRC}$, both countries are expected to integrate the CRC principle of the Best Interests of the Child (BIC; CRC Art. 3) into their legislation, policy, and provision of 
services. This principle establishes that signatory states "shall ensure that the institutions, services and facilities responsible for the care or protection of children shall conform with the standards established by competent authorities, particularly in the areas of safety, health, in the number and suitability of their staff, as well as competent supervision.” The BIC principle requires countries to treat all children equally, regardless of their national origin and immigration status in the country.

Today, migrant children are at the centre of a battle for the border. The robust regulatory framework to protect this group is under attack (Bhabha 2014a, 2014b; Kanics et al., 2010); efforts to protect these children have intensified. For example, in 2005 the UN Committee on the Rights of the Child outlined the legal obligations of signatory states towards unaccompanied and separated migrant children (UN Committee on the Rights of the Child, 2005). More recently, the UN has provided specific recommendations to find "sustainable, rights-based solutions" to their detention, deportation, and the preservation of family unity (UN Committee on the Protection of the Rights of All Migrant Workers and Members of their Families and the Committee on the Rights of the Child 2017). Other groups have come to the defence of child migrants, as we will see in the following pages, questioning the national security logic that dominates contemporary border-making.

A major challenge in the study of child migration is the lack of reliable and comparable statistical data (Kanics et al., 2010; Singleton, 2018). At a global scale, the UN estimates that child migrants (accompanied or otherwise) remained stable at around $1 \%$ of the total child population between 1990 and 2015; however, global population growth has meant a significant increase in the number of child migrants (UNHCR, UNICEF and IOM, 2017). Some of these children are also asylum seekers: nearly 100,000 unaccompanied children sought asylum in 78 
countries around the world in 2015 (UNICEF, 2016). Some countries publish statistics on unaccompanied migrant children at their borders; for example, the number detected at the USAMexico border has ranged between 15,949 in 2011 and 68,541 in 2014; the figure for 2018 was 50,036 (US Border Patrol, 2019). Other countries collect but do not share this information. There is no comprehensive information about unaccompanied migrant children crossing the EU's southern border (widely shared data refers only to minors who submit an asylum claim, which in some countries is fewer than one in six children). The Spanish government has not consistently released figures for the number of unaccompanied children apprehended at the border (APDHA, 2019; UNICEF, 2019). We do know, however, that 4.835 unaccompanied children were apprehended at the sea border in 2018 - an eight-fold increase compared to 2016 (Ministerio Fiscal, 2019). According to local NGOs working on Moroccan and Spanish coasts, government data provide a very conservative estimate on the migration of unaccompanied children (APDHA, 2019).

The increased visibility of migrant children in both the US and Spain takes place against the backdrop of the politicization, securitization, and criminalization of (a certain kind of) international human mobility. The discursive construction of some migrants as security threats has led to the integration of processes, categories, and techniques proper to criminal law into efforts to control and halt unwanted migration - a process known as "crimigration" (Stumpf 2006) that also affects minors.

\section{THE EMERGING GLOBAL BORDER REGIME: IMPLICATIONS FOR THE MIGRATION OF UNACCOMPANIED CHILDREN}

Borders have become the instrument of choice in managing international migration (Maillet et al., 2018). The border functions as a filter to sort desired from unwanted migrants, keeping the 
latter out and imposing the administrative categories defined by the state onto those who access national territory (de Genova, 2017; Jones, 2019; Maillet et al., 2018, Till et al., 2013; Vallet, 2017; Volpp, 2012). The ongoing transformation of borders worldwide has a profound impact on the possibilities and conditions of unaccompanied child migration.

Migration and border scholars have endeavoured to interpret the transformations in the conception, construction, and instrumentalization of borders to stop unwanted migration. During the 1990s and early 2000s, discussions focused on the predicted disappearance of the national border. When this did not happen, some scholars concluded that the toughening of national borders was testimony to states' waning sovereignty at the global scale - a sort of compensatory performance in the face of globalization (Brown, 2010; Cuttitta, 2014; de Genova, 2017). Since borders (in particular, border walls) "rarely succeed at interdiction" and are not cost-effective, Wendy Brown (2010: 9) concluded that border walls are "theater pieces for national populations specifically unsettled by global forces threatening sovereignty and identity at both the state and individual level". In this context, "migration crises" enable governments hostile to international migration to implement exceptional measures to reinforce the border and affirm the territorial sovereignty of the state (Maillet et al., 2018; Migreurop, 2018; Mountz, 2010; Williams and Mountz, 2018).

Since the turn of the century, three such "crises" have been instrumentalized to advance the reinforcement of the border in the USA and Europe: the 9/11 terrorist attacks, the peak of refugee arrivals in 2015, and the migrant "caravans" in 2018. These three moments have contributed to the merging of three seemingly disparate "wars" in the public imagination and in political practice: the war on crime, the war on global terrorism, and the war on spontaneous migration. Merging migration, crime, and terrorism provides the justification to implement 
drastic anti-immigration measures at the border (Dauvergne, 2016; Huysmans, 2006; Hyndman, 2012; van Houtum, 2010). The construction of spontaneous migration as a threat to national security has also contributed to the erosion of protections for particularly vulnerable migrant groups such as minors and asylum seekers.

\section{The multi-faceted border as an instrument of migration control}

The emerging global border regime relies on a combination of preventive and defensive measures. The former aim at pre-empting the departure of potential migrants from countries of origin and transit and include, for example, campaigns to discourage potential migrants from leaving, temporary and circular migration programs, development aid, and preferential trade agreements. Defensive measures aim to block spontaneous migrants' access to the national territory and/or and expel them from it and include externalization of migration enforcement, militarization of the border, migrant detention, and deportation. Both sets of measures are linked: for example, the transfer of EU and Spanish development funds to countries of origin and transit are made conditional on those countries accepting migrants deported from the EU. The growing importance of migration for countries' internal and international policy has resulted in the rise of “migration diplomacy", or "state's use of diplomatic tools, processes, and procedures to manage cross-border population mobility” (Adamson and Tsourapas 2019: 115-116). Migration diplomacy is the foundation of the global border regime, which depends on collaboration between countries of origin, transit, and destination of migrants and between these countries and other non-state and intergovernmental actors such as the International Organization for Migration (see, for example, Ashutosh and Mountz, 2011). 
Within this security logic, states instrumentalize the border to tackle spontaneous migration as undifferentiated and homogeneous. In doing so, the global border regime contributes to the erosion of international and domestic regulatory frameworks for the protection of children's rights. Four policy instruments at the core of the global border regime (externalization, militarization, detention, and deportation) affect the migration of unaccompanied children along the Spanish and US southern borders.

\section{Externalization}

Cooperation with countries of origin and transit of immigration enables countries of reception to transform and extend their influence and territorially extend their border. For the purposes of this paper, externalization is the most pertinent territorial strategy. ${ }^{1}$ This may involve the delegation of migration control responsibilities to cooperating governments in countries of origin and transit of migration; physical relocation of state security forces from the receiving country to countries of origin and transit to allow for direct surveillance (also known as extraterritorialisation); or both. Authors place the origin of externalization practices in the USA in the 1980s with the offshoring of maritime operations to the Caribbean (Loyd and Mountz, 2018). In the EU, externalization began with the signing of the Schengen agreement in 1985 (Maillet et al., 2018); it is well advanced in Spain (Casas-Cortés et al., 2014; Topak and Vives, 2018; Vives 2017).

Externalization has three main consequences. First, it creates "communities of practice" (Lave and Wegner, 1991) and networks of reciprocity and obligation, which in turn facilitate informal collaborations and rapid intervention during migration "crises" (Casas-Cortés et al.,

\footnotetext{
${ }^{1}$ Note that other territorial strategies are also in play but will not be addressed here: internalisation of the border (see for example Coleman and Kocher 2011; Nevins 2010), territorial excision (Vogl 2015), and other manipulations of the legal geographies of the border (Maillet et al. 2018).
} 
2014). Second, externalization shapes national priorities in countries of origin and transit to reflect the policy goals of the externalizing state, and results in policies that further criminalize and expose child migrants to exploitation and harm before they reach the border. For example, the EU's West African state security forces target those who "look like migrants" — that is, young black men wearing backpacks and hanging out in places where other migrants linger (Andersson, 2014). Third, collaborating countries tend to be poor, have democratic deficits and exhibit poor human rights records - these are governments that may be unable or unwilling to provide international protection to child migrants.

Spatially, externalization has transformed the border into "a territorially extended, increasingly informal and itinerant bordering assemblage of institutions, state authorities, and policies that react to dynamic and turbulent migratory movements" (Casas-Cortés et al. 2014: 2). But these novel expressions of border spatiality that stretch into jurisdictions hitherto beyond the reach of the receiving state and the emerging institutional architectures they require remain incomplete, fragmented, and ambiguous. They are built upon webs of relations between states, institutions, and areas of public policy often hidden from public scrutiny (Casas-Cortés et al., 2014). In practice, externalization creates buffer zones in spaces of transit of spontaneous migration and fosters a practice Hyndman and Mountz call neo-refoulement, "the strategy of preventing the possibility of asylum by denying access to sovereign territory" (2008: 268). Externalization traps child migrants in territories where their specific rights and entitlements are rendered irrelevant.

\section{Militarization}


Militarization can be defined as "the application of military logics, techniques, and technologies of border control by military or militarized police actors" (Topak and Vives, 2018). In the context of migration control, key militarized areas include the physical border of the state, while areas within cooperating countries of origin and transit of migration may also be militarized through externalization and extraterritorialization. In Spain, the main actors driving militarization are the Guardia Civil (a national force under the purview of the Ministries of Interior and Defence) and the European Border and Coast Guard Agency (EBCG or Frontex). In the USA, the main actors are the Immigration and Customs Enforcement agency (ICE) and the US Border Patrol, two US federal law enforcement agencies housed within the Department of Homeland Security.

The reinforcement of the border through its militarization clearly signals the primacy of national security concerns over international commitments for the protection of human rights. The militarized border is designed to reject all spontaneous migrants regardless of their specific circumstances, and prevents children, asylum seekers, refugees, and other migrants from being able to make a claim for protection. Combined with other policy changes to limit access to international protection (mainly, "turnbacks" or "pushbacks"), current efforts to militarize the southern USA border have channeled asylum seeking families and children from Central America to specific and highly secured points of entry where they have found increasing obstacles to submit an asylum claim, including practices such as "turnbacks" (refusing entry) and "metering" (limiting the number of asylum seekers who can submit a claim for international protection per day; Robert Strauss Center, Center for US-Mexican Studies and Migration Policy Centre 2018). A more recent initiative now developing but supported by a ruling by the Supreme Court in September 2019 seeks to deny asylum to any migrants passing through another country 
on their way to the US, effectively closing the door to the majority of asylum seekers (The Guardian, 2019).

In Spain, as in the rest of southern EU countries, the situation is similar. "Pushbacks" and mass returns at the border (the immediate transfer at the border of spontaneous migrants to authorities in the country from which they are coming) are routine (Topak and Vives, 2018). The European Tribunal of Human Rights concluded Spain has violated the European Convention on Human Rights with these "pushbacks" (European Court of Human Rights, 2017). Furthermore, designated offices for submission of asylum claims in the Spanish exclave of Ceuta are located beyond the militarized Moroccan border fence, already in Spanish territory: the only way to make a claim is to cross the border illegally.

Children are particularly vulnerable to violence that stems from militarization of the border (Androff, 2016; APDHA, 2019; Defensor del Menor de Andalucía, 2015; Thronson, 2018; UNICEF, 2019). The militarized border is designed to keep all unsolicited migrants out of the national territory, and the merging of migrants' specific circumstances is not an accident, but a desired outcome, as it allows the state to deny protection and ignore its international and domestic obligations towards migrant children and other migrants at risk.

\section{Detention}

The detention of spontaneous migrants has three main objectives. First, to punish those crossing the border illegally_-including asylum seekers, even though the Geneva Convention unequivocally states that asylum seekers should, under no circumstances, be punished for crossing the border illegally to make a claim for protection if they present their claim without delay (UN Assembly, 1951, Art. 31). Second, to deter future migrants. According to this 
rationale, migrants will be less likely to cross illegally if they know they will be detained. And third, to prevent migrants from absconding while their cases are being processed, thus facilitating their eventual deportation (Hiemstra, 2019). Detention of migrant children is usually considered a practice to be avoided.

Migrant detention is expensive, particularly when it involves children. Because minors require specialized care and facilities, in the USA detaining a migrant child costs two to six times per day more than detaining an adult, reaching up to $\$ 750$ per child per day (Human Rights Watch, per. comm.; Torbati and Cooke, 2019). While migrant detention (including that of children) in the US is mainly a private business that has expanded rapidly since the Obama administration (Hiemstra, 2019), migrant detention in southern Europe is a more recent and less common phenomenon, and detention centres are run mainly through public-private partnerships (Migreurop, 2016). In Spain, migrant children may be detained while their minority is in doubt and are usually released if they are proven to be minors. Otherwise, children are placed in specialized youth protection centres in Spain. But cumbersome, hard-to-access and generally inaccurate age determination procedures can be considered part of Spain's bordering efforts. The medical tests routinely used in Spain have a four-year confidence range, are not reliable, expose children to harm, and are invasive (García García, 2017). These tests include, for example, the physical examination of teenagers' sexual development by medical teams. For these reasons, the use of such age determination procedures by the Spanish government is a violation of the BIC principle (Fundación Raíces, 2014; García García, 2017; UNICEF, 2019).

Perhaps paradoxically, given the criminalization of migration, the administrative detention of migrants does not come with the safeguards and procedural protections built into the criminal justice system, making migrants more vulnerable than other people imprisoned by the 
state (Atak and Simeon, 2018; González Sánchez, 2016). Besides, detention may happen in facilities that are not officially designated detention centres or prisons; often, migrants are also held in "temporary internment centres", "hotspots" or processing centres, which are designed for short-term migrant detention and do not need meet the criteria for space allocated to each inmate, minimum sanitary conditions, or programming that usually apply to centres for the general population. Technically, they are not detention centres, and children housed in these "temporary" facilities are not included in official detention statistics. While migrant children are, as mentioned above, placed in detention in US territory, Spain tends to externalize detention to transit countries such as Mexico and Mauritania (Global Detention Project, 2010, 2014). We do not know how many migrant minors may be in detention in these countries.

The mental and physical health consequences of detention increase with time spent in detention and are particularly harmful and irreversible in children (Gros and Song, 2016). For this reason, human rights instruments demand that detention be used as the very last resort, have the shortest possible duration, and privilege the integrity of the family unit. International efforts have focused on the protection of unaccompanied children in detention in countries of transit and destination (see, for example, UN Committee on the Protection of the Rights of All Migrant Workers and Members of Their Families , 2017; UN Committee on the Rights of the Child, 2005).

\section{Deportation}

Deportation is the expulsion of a migrant from the receiving country. There are two main types of deportation. The first kind, already introduced above, takes place immediately following the crossing of the border; these deportations are referred to as "turnbacks," "pushbacks", or "mass 
deportations" (Robert Strauss Center, Center for US-Mexican Studies and Migration Policy Centre, 2018; Topak and Vives, 2018) and are a direct consequence of border militarization. For example, Spain routinely hands spontaneous migrants to Morocco, both at sea and along the land border, without ever going through their individual files. Mass deportations disregard the individual circumstances of those deported, who may be minors or otherwise entitled to particular protections. These practices violate domestic, regional, and international commitments, particularly when they involve minors, including the Universal Declaration of Human Rights, the European Convention on Human Rights, the EU's 2008 common rules on return (also known as "the Return Directive"), the Convention Relating to the Status of Refugees, and the United Nations Convention on the Rights of the Child, among others (Bhabha, 2014b).

A second form of deportation follows a period within the territory of the receiving state, including in a detention or detention-like facility. Unlike "turnbacks" and "pushbacks," formal deportations usually involve the judicial system. Deporting migrants is expensive: in 2016, ICE spent an average $\$ 10,854$ per migrant deported, a figure that includes costs associated with apprehension and detention (Blanco, 2017). Frontex spent around $€ 5,400$ per deportee in 2017, not including other costs, such as detention (Civillini and Bagnoli, 2017).

Migrant children experience all these forms of deportation in the two contexts considered here, although in Spain children tend to be deported before they have been able to demonstrate their status as children (Defensor del Menor 2018) - unless they are Moroccan nationals, in which case the reactivation of the 2012 agreement between the two countries allows for their deportation regardless of their age. Deportations depend on the acceptance of the countries that will receive deported migrants, which are not always their countries of citizenship. Because 
deportation is central to the emerging global border regime (Gibney, 2008), states have sought to improve relations with origin and transit countries and encourage the readmission of unwanted migrants (Casas-Cortés et al., 2014; Topak and Vives, 2018; Hiemstra, 2019). A final form of deportation that is becoming increasingly important in practice is "voluntary return" (Ashutosh and Mountz, 2011; Webber, 2011), which will not be considered here.

\section{REGIONAL VARIATIONS OF THE GLOBAL BORDER REGIME IN SPAIN AND THE USA: IMPLICATIONS FOR THE PROTECTION OF UNACCOMPANIED AND SEPARATED MIGRANT CHILDREN}

Unaccompanied migrant children tend to use the same migratory routes as adults. This means that, as argued in the previous sections, the defensive measures implemented at the border directly affect children's conditions for migration and their access to protection. In this section, I focus on how the US and Spanish regional variations of the global border regime have different, but equally troubling, consequences for this group.

\section{Spain: Out of sight, out of mind}

Migrant children's detention in and deportation from Spanish territory are rare and, as discussed above, usually happen before the migrant's status as a child has been proven. The Spanish border regime's main impact on the migration of unaccompanied children happens through the externalization and militarization of the border, which have placed significant obstacles for migrant children to access Spanish territory and seek protection. Militarization of the southern EU border was pioneered in the area between Morocco and Spain in the early 2000s and depends on deep and ongoing - if difficult - cooperation between these two countries (Vives, 2017; 
Topak and Vives 2018). This cooperation allows Spanish authorities to hand over a migrant boats to their Moroccan counterparts while still at sea, with no arrangements for children to identify themselves as such. Additionally, this same cooperation facilitates the quick deportation of children while they wait for the results of their age determination tests (Fundación Raíces, 2017).

Even minors who succeed in crossing the militarized border and accessing Spanish territory face difficult prospects. If they are accepted as minors by the police upon arrival, these children are immediately transferred to youth protection services. The Spanish government recently reactivated a 2012 bilateral agreement to facilitate the deportation of unaccompanied migrant children to Morocco, the main country of origin of these minors. Non-Moroccan minors and others who cannot be deported are placed in the custody of relatives residing in Spain or to regional youth protection agencies. A troubling fact is that over $73 \%$ of those placed in youth protection centres in Andalusia (the region of first arrival of virtually all minors by sea) disappear; organizations working with these youth believe they leave these centres because they wish to fulfil a migratory project of their own (sometimes in other parts of Spain or in other European countries) or because they fall prey to exploitative criminal networks (Defensor del Pueblo, 2018; UNICEF, 2019).

In 2006, Fundación Raíces (an NGO working for the protection of vulnerable youth) denounced the government for carrying out medical testing even when solid documentation proved the children were minors (e.g. a passport and a certified birth certificate accepted as valid by the country of origin's consulate in Spain). According to their report, authorities brought migrant children as young as 12 to a specific private clinic that would systematically conclude migrants who had identified themselves as children were over 18 years of age (Fundación 
Raíces, 2014, 2017). These potential minors were declared deportable and detainable in facilities not destined for children; and they were also unable to access youth protection services and any other services provided by the state, even if they had official documentation attesting to their being children, because the age determined by the state prevailed over any other documentation. They ended up either in prison, on the street, or in a plane bound to one of Spain's partner countries in Africa. Among the experiences documented, some children were deported to cities as far as 600 kilometres from their hometowns without resources to make it home (Fundación Raíces, 2014). The organization brought these government practices to court in 2009 and won, but as of late 2019 Spanish authorities have yet to integrate the ruling and the recommendation of the ombudsperson (Defensor del Menor de Andalucía 2015) into their policy and practice.

Together, these practices constitute a systematic violation of unaccompanied migrant children's rights. First, militarization and the delegation of border control responsibilities (externalization) to Moroccan authorities directly feed into the systematic denial of specific protections to this group observed in international, European, and Spanish legislation. Second, when these children access national territory, the Spanish government goes to great lengths to ensure the deportability of children through unreliable and invasive age determination tests. Spanish efforts to evade their responsibilities force migrant children to conditions of extreme vulnerability, including detention with the adult population, homelessness, and unsafe deportation.

\section{The USA: Mistreatment as a form of deterrence}

Contemporary border policy along the southern US border also violates children's rights and is in direct conflict with the BIC principle. Much like in Spain, this is the result of a border 
architecture that is hostile to spontaneous migration in general and that relies mainly on the policy instruments discussed above (externalization, militarization, detention, and deportation) and that affects children in specific ways. But, unlike in Spain, US border policies target children specifically.

The detention of migrant children, which was not widely used until the election of Donald Trump in 2016, feeds on and fuels the criminalization of this group. This in turn justifies its subjection to policies and processes usually identified with the criminal justice system. Furthermore, the mandatory detention of adult asylum seekers until their cases are resolved or they are deported requires family separation, as minors must be placed in dedicated facilities. Upon separation, children are placed under the care of the Office of Refugee Resettlement (ORR), housed in shelters, and eventually released to relatives, state institutions, or foster care families; in some cases, they have been given up for adoption without the knowledge or consent of their biological families (Associated Press, 2018). There are no channels of communication between ORR and the Office of Enforcement and Removal Operations that manages migrant detention, making family reunification difficult (Soboroff and Romero, 2019). In the best of circumstances, separating children from their parents and detaining them in prison-like settings constitutes a form of torture with long-term and wide-ranging consequences for the physical and psychological health of these children (Gros and Song 2016). But the conditions of child detention in the US can be far from ideal: between 2014 and 2018, the ORR received 4,556 allegations of sexual abuse or harassment of migrant children in US custody (Haag, 2019). In December 2018, there were an estimated 15,000 migrant children in detention in the USA (Jordan, 2018). 
While the forced separation and widespread detention of children is perhaps the most distinctive feature of the contemporary US border regime, other policy instruments used also affect this migrant group. The militarization of the southern border has relied heavily on the expansion and reinforcement of the border wall between the US and Mexico, deployment of military personnel along the border, and further militarization of the Border Patrol (Jones, 2016). These measures have funneled migrants towards specific sections and ports of entry along the wall, allowing for the adoption of hardline approaches to the management of migrants' claims to international protection (Robert Strauss Center, Center for US-Mexican Studies and Migration Policy Centre, 2018). With the equation of asylum seekers reaching the US border with a security threat that must be handled through military means, the entire legal system for the protection of this group (which includes a sizeable child population) has been rendered irrelevant.

The deportation of child migrants from the US is on the rise. But the main threat to children showing up at the border to claim asylum (a right shrined in both international and national legislation) is permanent separation from their families. In other words, US border policy creates unaccompanied migrant children where there used to be none. Civil society groups such as the American Civil Liberties Union and NGOs like Save the Children, among many others, have organized to resist this practice and support detained children and their families; key elected representatives have also made fighting the detention of migrant children at the border a personal mission, notably Democrat Alexandria Ocasio-Cortez. Much like in the case of Spain, this resistance has borne little fruit.

\section{CONCLUSIONS}


In this paper, I have focused on the contemporary migration of unaccompanied children in the USA and Spain to test the argument, put forward by Catherine Dauvergne (2016), that the emerging and fundamentally "nasty" global border regime is rendering differences between former colonial powers and settlement societies irrelevant. Since migrant children enjoy the most robust set of internationally and domestically sanctioned protections, I have focused on this group to test the convergence towards a repressive global border regime defined by its nastiness.

The systematic violation of children's rights at and beyond the borders of the US and Spain shows just how far states have gone putting national security concerns over the protection of human rights. The evidence reviewed in this article shows that a new form of border has emerged, one that departs from the actual territorial limit of the state to become an assemblage of contiguous and noncontiguous spaces articulated to heighten the state's capacity to control and halt unwanted human mobility. It also shows that this regime is built upon the securitization and criminalization of spontaneous human migration and that "crises" have been crucial to justify the roll out of its most controversial aspects, including the detention of children, which have now become normalized. This emerging regime relies on four main policy instruments: externalization of border and immigration control policies, militarization of the border, immigrant detention, and deportation. This new border regime has already been rolled out in places as seemingly disparate as the US and Spain, marking a departure from traditional distinctions between settlement colonies and former colonial powers in migration scholarship.

This new way of using the border to halt unwanted migration is particularly harmful for unaccompanied migrant children. In enables destination states to treat spontaneous migration as an undifferentiated whole, thus ignoring their obligations to migrants deserving specific protections such as children. Furthermore, such protections may be rendered irrelevant in 
countries of transit which have agreed to act as external border guards for the US or Spain. Detention of migrant children (rare in Spain but widespread in the US) further demonstrates the lengths to which receiving states are willing to go to "secure" their border, even at the expense of violating their own international commitments and domestic laws. The primacy of national security concerns over human rights and the application of these four policy instruments makes current border policy particularly "nasty", and current migration and border policy are an unmitigated catastrophe for the protection of unaccompanied migrant children.

But the question remains: Can we talk about a global border regime? If it exists, its geographical scope is still limited to some countries and thus cannot be defined as "global" - at least, not yet. Even though the ideology supporting this regime and the policy instruments enabling it may be embraced in seemingly disparate locales worldwide - supporting the idea that policy ideas "travel” (Peck and Theodore, 2015) - we see important regional variations. Factors that explain this variation include existing institutions that shape the articulation of this ideology in practice; governments that favour specific policy instruments over others (e.g. detention in the USA, externalization in the EU); and civil society and other actors' mobilization to rein in the impulse to close the border at the expense of human rights.

A coherent set of instruments and transnational or supranational institutions involved in its making has enormous potential for the creation of a more just and integrated system for the protection of migrant children's rights. Attempts to protect these minors against the rhetoric of fear have so far been only partially successful and highly controversial, as the negotiations and outcomes of the Global Compacts on migration and refugees demonstrated. However, these first attempts to counter the primacy of national security concerns provide valuable guidelines for implementation of policy instruments for the protection of migrant children. Guided by this and 
other documents, four policy recommendations are fundamental to protect unaccompanied migrant children in the US and Spain and wherever they may be subjected to similar treatment:

1. The foundation for all decisions on unaccompanied migrant children should be the BIC principle. Because this principle is (or should be) already largely integrated in most legal and regulatory frameworks both in the USA and in Spain, both countries should implement current laws and regulations designed to protect minors at risk. The BIC principle should also be integrated into all agreements with cooperating governments in countries of origin and transit of child migrants to ensure the protection of this group in all spaces articulated into the destination country's border enforcement efforts.

2. Countries should

[p]rotect unaccompanied and separated children at all stages of migration through the establishment of specialized procedures for their identification, referral, care and family reunification, and provide access to health care services, including mental health, education, legal assistance and the right to be heard in administrative and judicial proceedings, including by swiftly appointing a competent and impartial legal guardian, as essential means to address their particular vulnerabilities and discrimination, protect them from all forms of violence, and provide access to sustainable solutions that are in their best interests (UN Assembly, 2019, paragraph 16).

3. Countries should avoid placing children in detention or detention-like facilities. Minors should not be detained for immigration-related reasons, and countries should privilege community-based alternatives to detention. If there are no other alternatives, there should always be legislated and respected time limits for the detention of children; these minors should be in low-security facilities staffed by properly trained and screened personnel. 
4. Deportation should happen only when it is in the best interest of the child, through safe channels, in the presence of the child's legal guardian or a trained professional, making sure the child will be safely transferred to a community where their rights will be protected.

\section{REFERENCES}

Adamson, F.B., and G. Tsourapas

2019 “Migration diplomacy in world politics", International Studies Perspectives, 20(2): 113-128.

Andersson, R.

2014 Illegality, Inc. Clandestine Migration and the Business of Bordering Europe, California University Press, Oakland.

Androff, D. J.

2017 "The Human Rights of Unaccompanied Minors in the USA from Central America", Journal of Human Rights and Social Work, 1(2):71-77.

Atak, I. and J.C. Simeon (editors)

2018 The Criminalization of immigration: context and consequences, McGill University Press, Montreal.

APDHA

2019 “Infancia migrante. Derechos humanos en la frontera sur 2019”, https://www.apdha.org/informeinfancia-migrante/\#.

Ashutosh, I., and A. Mountz

2011 "Migration management for the benefit of whom? Interrogating the work of the International Organization for Migration", Citizenship Studies, 15(1), 21-38.

Associated Press

2018 "Deported parents may lose kids to adoption, investigation finds", October 9. https://www.nbcnews.com/news/latino/deported-parents-may-lose-kids-adoption-investigationfinds-n918261. 
Bhabha, J.

2014a "Moving children: Lacunae in contemporary human rights protections for migrant children and adolescents", Revue européenne des migrations internationales, 30(1): 35-57.

2014b Child Migration and Human Rights in a Global Age, Princeton University Press, Princeton.

Blanco, O.

2017 "How much it costs ICE to deport an undocumented immigrant", CNN Business. https://money.cnn.com/2017/04/13/news/economy/deportation-costs-undocumentedimmigrant/index.html.

Brown, W.

2010 Walled States, waning sovereignty. Zone Books: New York, NY.

Casas-Cortés M., S. Cobarrubias, and J. Pickles

2014 “'Good neighbours make good fences': Seahorse operations, border externalization and extraterritoriality", European Urban and Regional Studies, 23(3): 231-251.

Civillini, M., and L. Bagnoli

2017 “Skyrocketing costs for returning EU migrants", euobserver, May 5. https://euobserver.com/migration/137720.

Coleman, M., and A. Kocher

2011 "Detention, deportation, devolution and immigrant incapacitation in the US, post 9/11", The Geographical Journal, 177(3): 228-237.

Cuttitta, P.

2014 “"Borderizing' the island setting and narratives of the Lampedusa 'border play"”, ACME, 13(2): 196-219.

Dauvergne, $\mathrm{C}$.

2016 The New Politics of Immigration and the End of Settler Societies, Cambridge University Press, New York. 
Defensor del Menor de Andalucía

2015 "Informe anual 2015".

https://www.observatoriodelainfancia.es/ficherosoia/documentos/4967_d_dma-informe2015_publicar_0.pdf.

Defensor del Pueblo

2018 “Procedimiento de determinación de la edad”, September 13.

https://www.defensordelpueblo.es/resoluciones/dictar-una-instruccion-para-recordar-a-los-

fiscales-la-necesidad-de-dictar-decreto-de-mayoria-de-edad-y-notificarlo-a-los-interesados-conanterioridad-a-la-materializacion-de-su-devolucion/.

de Genova, N.

2017 The Borders of "Europe” Autonomy of Migration, Tactics of Bordering, Duke University Press, Durham, NC.

European Court of Human Rights

2017 Affaire N.D. et N.T. c. Espagne (requêtes nos. 8675/15 et 8697/15).

https://hudoc.echr.coe.int/eng\#\{\%22itemid\%22:[\%22001-177231\%22]\}.

Fundación Raíces

2014 "Sólo por estar solo. Informe sobre la determinación de la edad en menores migrantes no acompañados". http://www.fundacionraices.org/wp-content/uploads/2014/05/SOLO-PORESTAR-SOLO.pdf.

2017 “Unaccompanied migrant children in Spain”, http://www.fundacionraices.org/wpcontent/uploads/2018/01/Alternative-report-executive-summary.pdf.

García García, T.

2017 El procedimiento para la determinación de la edad de los extranjeros no acompañados. Bases para un nuevo modelo, $\mathrm{PhD}$ dissertation, Department of Law, Universidad Pontificia de Comillas, Madrid.

Gibney, M.J. 
2008 "Asylum and the expansion of deportation in the United Kingdom," Government and Opposition, 43(2): 146-167.

\section{Global Detention Project}

2010 Mauritania Immigration Detention Profile. https://www.globaldetentionproject.org/countries/africa/mauritania.

2014 Morocco Immigration Detention Profile. https://www.globaldetentionproject.org/countries/africa/morocco.

González Sánchez, I.

2016 "La penalización de los migrantes: irregularidad y cárcel en la construcción del estado neoliberal", Migraciones, 39: 123-147.

Gros, H., and Y. Song

2016 "No place for a child: A roadmap to end immigration detention of children and family separation", https://ihrp.law.utoronto.ca/utfl_file/count/PUBLICATIONS/Report-NoLifeForAChild.pdf

\section{The Guardian}

2019 "Supreme Court decision to let Trump deny asylum reverses years of US policy", September 12, https://www.theguardian.com/us-news/2019/sep/11/trump-supreme-court-deny-asylumimmigrants.

Haag, M.

2019 "Thousands of immigrant children say they were sexually abused in U.S. detention centres, report says", February 27. https://www.nytimes.com/2019/02/27/us/immigrant-children-sexualabuse.html

Hiemstra, N.

2019 Detain and Deport: The Chaotic U.S. Immigration Enforcement Regime, University of Georgia Press, Athens.

Huysmans, J.

2006 The Politics of Insecurity: Fear, Migration and Asylum in the EU, Routledge, London and New York. 
Hyndman, J.

2012 "The geopolitics of migration and mobility", Geopolitics, 17(2): 243-255.

Hyndman, J., and A. Mountz

2008 "Another brick in the wall? Neo-refoulement and the externalization of asylum by Australia and Europe", Government and Opposition, 43(2): 249-269.

International Committee of the Red Cross

1949 "Geneva Convention Relative to the Protection of Civilian Persons in Time of War", 12 August 1949, 75 UNTS 287, https://www.refworld.org/docid/3ae6b36d2.html.

Johnson, C., Jones, R., Paasi, A., Amoore, L., Mountz, A., Salter, M., \& Rumford, C.

2011 "Interventions on rethinking 'the border' in border studies", Political Geography, 30(2): 61-69.

Jones, R.

2016 Violent Borders. Refugees and the Right to move, Verso, London.

Jones, R. (editor)

2019 Open Borders: In Defence of Free Movement, University of Georgia Press, Athens.

Jordan, M.

2018 "Thousands of migrant children could be released after sponsor policy change", New York Times, December 18. https://www.nytimes.com/2018/12/18/us/migrant-children-releasepolicy.html?rref=collection\%2Ftimestopic\%2FImmigration\%20Detention\&action=click\&content Collection=timestopics\&region=stream\&module=stream_unit\&version=latest\&contentPlacement =2\&pgtype=collection.

Kanics, J., D. Senovilla Hernández, and K. Touzenis (editor)

2010 Migrating Alone: Unaccompanied and Separated Children's Migration to Europe, UNESCO Publishing, Paris.

Lave, J., and E. Wenger

1991 Situated Learning: Legitimate Peripheral Participation, Cambridge University Press, New York. 
Loyd, J., and A. Mountz

2018 Boats, Borders, and Bases: Race, the Cold War, and the Rise of Migration Detention in the United States, University of California Press, Oakland.

Maillet, P., A. Mountz, and K. Williams

2018 "Exclusion through imperio: Entanglements of law and geography in the waiting zone, excised territory and search and rescue region”, Social \& Legal Studies, 27(2): 142-163.

Migreurop

2016 “La détention des migrants dans l'Union européenne : un business florissant : Sous-traitance et privatisation de l'enfermement des étrangers". http://www.migreurop.org/article2761.html.

2018 Atlas des migrants en Europe: géographie critique des politiques migratoires. Paris: Armand Colin.

Ministerio Fiscal

2019 “Memoria 2018”. https://www.fiscal.es/memorias/memoria2018/Inicio.html.

Mountz, A.

2010 Seeking Asylum: Human Smuggling and Bureaucracy at the Border, University Minnesota Press, Minneapolis.

Nevins, J.

2010 Operation Gatekeeper and Beyond: The War On "Illegals" and the Remaking of the U.S.-Mexico Boundary, Routledge, New York.

Peck, J. and Theodore, N. (2015) Fast Policy: Experimental Statecraft at the Thresholds of Neoliberalism. Minneapolis: University of Minnesota Press.

Robert Strauss Center, Center for US-Mexican Studies and Migration Policy Centre

2018 "December Asylum processing and waitlists at the U.S.-Mexico border". http://strausscenter.org/images/MSI/AsylumReport_MSI.pdf.

Singleton, A. 
2018 "Data: Creating the empirical base for development of child migration policy and protection”. In J.

Bhabha., J. Kanics, and D. Senovilla Hernández, Research Handbook on Child Migration, Edward Elgar Publishing, Northampton: 334-344.

Soboroff, J., and D. Romero

2019 "Finding all migrant children separated from their families may be impossible, feds say", NBC News, February 2. https://www.nbcnews.com/news/us-news/finding-all-migrant-childrenseparated-their-families-may-be-impossible-n966266.

Stumpf, J.

2006 "The crimmigration crisis: Immigrants, crime, and sovereign power", American University Law Review, 56(2): 367-420.

Thronson, D.B.

2018 "Children's rights and U.S. immigration law”, in J. Bhabha., J. Kanics, and D. Senovilla Hernández (editors), Research Handbook on Child Migration, Edward Elgar Publishing, Northhampton, $157-172$.

Till, K.E., J. Sundberg, W. Pullan, C. Psaltis, C. Makriyianni, R.Z. Celal, M.O. Samani, L. Dowler 2013 "Interventions in the political geographies of walls", Political Geography, 33(1): 52-62.

Topak, Ö., and L. Vives

2018 "A comparative analysis of migration control strategies along the Western and Eastern Mediterranean routes: Sovereign interventions through militarization and deportation", Migration Studies (online).

Torbati, Y., and K. Cooke

2019 “First stop for migrant kids: For-profit detention center". https://www.reuters.com/article/us-usaimmigration-children/first-stop-for-migrant-kids-for-profit-detention-center-idUSKCN1Q3261.

UN General Assembly

1951 "Convention Relating to the Status of Refugees”, 28 July 1951, United Nations, Treaty Series, vol. 189, p. 137, https://www.refworld.org/docid/3be01b964.html 
1967 "Protocol Relating to the Status of Refugees", 31 January 1967, United Nations, Treaty Series, vol. 606, p. 267, https://www.refworld.org/docid/3ae6b3ae4.html

1989 "Convention on the Rights of the Child”, 20 November 1989, United Nations, Treaty Series, vol. 1577, p. 3, https://www.refworld.org/docid/3ae6b38f0.html

2019 "Global Compact for Safe, Orderly and Regular Migration", https://refugeesmigrants.un.org/sites/default/files/180713_agreed_outcome_global_compact_for_ migration.pdf

UN Committee on the Protection of the Rights of All Migrant Workers and Members of Their Families 2017 "Joint general comment no. 4 of the Committee on the Protection of the Rights of All Migrant Workers and Members of Their Families and no. 23 of the Committee on the Rights of the Child on state obligations regarding the human rights of children in the context of international migration in countries of origin, transit, destination and return", 16 November, CMW/C/GC/4CRC/C/GC/23. https://www.refworld.org/docid/5a12942a2b.html.

UN Committee on the Rights of the Child

2005 "General comment no. 6 (2005): Treatment of unaccompanied and separated children outside their country of origin", 1 September 2005, CRC/GC/2005/6. https://www.refworld.org/docid/42dd174b4.html.

UNHCR, UNICEF, and IOM

2017 "Refugee and migrant children in Europe: Overview of trends 2017". https://reliefweb.int/report/world/refugee-and-migrant-children-europe-overview-trends-2017.

\section{UNICEF}

2016 "Uprooted. The growing crisis for refugee and migrant children". https://data.unicef.org/resources/uprooted-growing-crisis-refugee-migrant-children/

2019 "Los derechos de los niños y niñas migrantes no acompañados en la frontera sur española". https://www.unicef.es/sites/unicef.es/files/recursos/informe-ninos-migrantes-noacompanados.pdf.

United States Border Patrol 
2019 “Total unaccompanied alien children (0-17 years old) apprehensions by month —FY 2010”. https://www.cbp.gov/sites/default/files/assets/documents/2019-Mar/bp-total-monthly-uacs-sectorfy2010-fy2018.pdf.

Vallet, E.

2013 "Des murs d'argent : Et la frontière devint un marché prospère et militarisé". https://blog.mondediplo.net/2013-11-29-Et-la-frontiere-devint-un-marche-prospere-et.

2017 Borders, Fences and Walls: State of Insecurity? Routledge, New York.

van Houtum, $\mathrm{H}$.

2010 "Human blacklisting: The global apartheid of the EU's external border regime", Environment and Planning D: Society and Space, 28(6): 957-976.

Vives, L.

2017 "Unwanted sea migrants across the EU border: The Canary Islands", Political Geography, 61: 181192.

Vogl, A.

2015 "Over the borderline: A critical inquiry into the geography of territorial excision and the securitization of the Australian border", UNSW Law Journal, 38(1): 114-145.

Volpp, L.

2012 "Imaginings of space in immigration law", Law, Culture and the Humanities, 9(3): 456-474.

Webber, F.

2011 "How voluntary are voluntary returns?", Race and Class, 52(4): 98-107.

Williams, K., and A. Mountz

2018 "Between enforcement and precarity: Externalization and migrant deaths at sea", International Migration, 56(5): 74-89. 